\title{
Synthesis, Molecular Docking and Antimicrobial Activities of 5-(4-substituted-benzyl)-2-(furan/thiophen-2- ylmethylene hydrazono)thiazolidin-4-ones
}

\author{
Taras Chaban ${ }^{1(\mathbb{D})}$, Volodymyr Horishny ${ }^{1}{ }^{(\mathbb{D})}$, Mohammad Arshad ${ }^{2(1)}$, Zoriana Chulovska ${ }^{1}$ (D), Liubov \\ Kostyshyn ${ }^{1}{ }^{(\mathbb{D}}$, Iryna Drapak ${ }^{1}{ }^{(\mathbb{D})}$, Vasyl Matiychuk ${ }^{3(\mathbb{C})}$ \\ 1 Danylo Halytsky Lviv National Medical University, Pekarska 69, Zip Code: 79010, Lviv, Ukraine; chabantaras@ukr.net \\ (T.C.); \\ 2 College of Medicine, Shaqra University, Zip Code: 11911, Al-Dawadmi, Saudi Arabia; mohdarshad1985@gmail.com \\ (M.A.); \\ 3 Ivan Franko National University of Lviv, 6 Kyryla and Mefodia, Zip Code: 79005, Lviv, Ukraine; v_matiychuk@ukr.net \\ (V.M.); \\ * Correspondence: chabantaras@ukr.net;
}

Scopus Author ID 55180682800

Received: 8.12.2020; Revised: 2.01.2021; Accepted: 4.01.2021; Published: 6.01.2021

\begin{abstract}
In our present work, we reported an effective synthesis, molecular docking, and antimicrobial properties of novel 5-(4-substituted-benzyl)-2-(furan/thiophen-2-ylmethylene hydrazono) thiazolidin4-ones (6a-g) and (7a-i). The structures of the synthesized compounds (6a-g) and (7a-i) were elucidated by ${ }^{1} \mathrm{H}-\mathrm{NMR}$ spectroscopy. The molecular docking studies were performed for all the synthesized compounds against GlcN-6P using AutoDock-tools-1.5.6 and recorded the extent of H-bonding and binding affinities. The preselected compounds via molecular docking were further tested for in vitro antimicrobial activity against five bacterial strains (Escherichia coli, Klebsiella pneumoniae, Acinetobacter baumannii, Pseudomonas aeruginosa, Staphylococcus aureus) and two fungal strains (Candida albicans and Cryptococcus neoformans). The antimicrobial findings exhibited that the compounds possessed significant antimicrobial potential.
\end{abstract}

Keywords: organic synthesis; thiazolidin-4-one; furan; thiophen; characterization; molecular docking; antimicrobial activity.

(C) 2020 by the authors. This article is an open-access article distributed under the terms and conditions of the Creative Commons Attribution (CC BY) license (https://creativecommons.org/licenses/by/4.0/).

\section{Introduction}

At present, medicinal chemists' main task is to find out the effective and less-toxic drugs with low molecular weight. The search has been carried out among the various classes of compounds, in particular 4-thiazolidone derivatives. Among these compounds, various compounds have been observed as highly active agents with a wide range of biological potential. Lead compounds with antimicrobial, antitubercular, antiviral, antidiabetic, antiinflammatory, antitumor, anticonvulsant, and other activities have been identified. Therefore, the 4-thiazolidone cycle is considered a privileged structure in medicinal chemistry [1-3].

One of the effective approaches in designing new drugs is to combine diverse structural fragments in one molecule. It is accompanied by the achievement of biosynergism $[4,5]$, which leads to a new pharmacological profile, potentiation of action, and reduction of toxicity of "hybrid" molecules. It was believed that there would be an enhancement in the valuable pharmacological properties of the aimed compounds, which will possess 4-thiazolidone cycle 
furan and thiophene moieties. Therefore, the study aimed at creating the methods for obtaining combinatorial libraries of compounds of this type and screening their biological properties is an urgent problem today.

Among 4-thiazolidone derivatives, it was observed that 5-arylidene-4-thiazolidones are the most studied derivatives as per the reported literature [1-3]. Among these derivatives, 5arylidene-2- (aryl-2-ylmethylenehydrazono) -thiazolidin-4-ones were reported to portray the antimicrobial [6-11], antiviral [11], antitumor [12,13] activities and also observed to be the inhibitors of various ferments [14-16]. On the other hand, less conformationally restricted derivatives of 5-benzyl-4-thiazolidone are practically not studied.

Due to our ongoing efforts to find out some better antimicrobial agents, we recently have reported the synthesis characterization, molecular docking, and biological assessment of 1, 3-thiazolidin-4-one derivatives bearing pyrimidine moieties and 1,3-thiazolidin-4-one bearing piperonal and pyrimidine moieties [17-18]. We have performed many studies aiming at the biological heterocycles as potential antimicrobial agents [19-48].

The recent study aimed to synthesize 5-(4-substituted-benzyl)-2-(furan/thiophen-2ylmethylenehydrazono) thiazolidin-4-ones, molecular docking, and antimicrobial assessment and believed that the fusion of the 4-thiazolidone cycle, furan and thiophene moieties would be a good effort for finding better antimicrobial agents.

\section{Materials and Methods}

\subsection{Materials.}

The reagents used for the synthesis of the target compounds were commercially available and of analytical grade. All solvents and reagents like 5-arylfurfural, heterylacetonitrile, ethanol, piperidine, dimethylformamide, ethyl acrylate, substituted aryldiazonium salts, copper bromide, thiophene-2-carboxaldehyde, furfural, glacial acetic were used without further purification.

\subsection{Chemistry.}

The melting points of all the compounds were recorded in an open capillary by Melt temp instrument. ${ }^{1} \mathrm{H}-\mathrm{NMR}$ spectra were registered on a Varian Mercury $400\left(400 \mathrm{MHz}\right.$ for $\left.{ }^{1} \mathrm{H}\right)$ instrument with TMS or deuterated solvent as an internal reference. Chemical shifts were reported as $\delta(\mathrm{ppm})$. Elemental analysis was performed on a Vario MICRO cube automatic CHNS analyzer. The elemental analysis data obtained experimentally for the contents of carbon, hydrogen, and nitrogen were within $\pm 0.3 \%$ of the theoretical values.

General procedure for the preparation of 5-(4-substitutedbenzyl)-2(furan/thiophen-2-ylmethylenehydrazono) thiazolidin-4-ones (6a-g) and (7a-i): The 0.01 mol of 5-arylfurfural 3a-e and 0.01 mol of heterylacetonitrile $7 \mathrm{a}, \mathrm{b}, 8$ or 9 was dissolved in 20 $\mathrm{ml}$ of ethanol in the presence of 2 drops of piperidine. The flask was refluxed for $1 \mathrm{~h}$. The precipitate formed was filtered off, washed with alcohol, and the product was purified by recrystallization from a mixture of ethanol-DMF.

2-(Furan-2-ylmethylenehydrazono)-5-(3-methylbenzyl)thiazolidin-4-one

(6a). Yield $81 \%, \mathrm{mp}=209-210^{\circ} \mathrm{C} .{ }^{1} \mathrm{H}-\mathrm{NMR}(400 \mathrm{MHz}, \mathrm{DMSO}) \delta 11.95(\mathrm{~s}, 1 \mathrm{H}, \mathrm{NH}), 8.19(\mathrm{~s}, 1 \mathrm{H}$, $\mathrm{CH}=), 7.83\left(\mathrm{~d}, \mathrm{~J}=1.6 \mathrm{~Hz}, 1 \mathrm{H}\right.$, furane), $7.21\left(\mathrm{t}, \mathrm{J}=7.5 \mathrm{~Hz}, 1 \mathrm{H}, \mathrm{C}_{6} \mathrm{H}_{4}\right), 7.10-7.01\left(\mathrm{~m}, 3 \mathrm{H}, \mathrm{C}_{6} \mathrm{H}_{4}\right)$, $6.93(\mathrm{~d}, \mathrm{~J}=3.4 \mathrm{~Hz}, 1 \mathrm{H}$, furane ), $6.62(\mathrm{dd}, \mathrm{J}=3.4,1.8 \mathrm{~Hz}, 1 \mathrm{H}$, furane), 4.60 (dd, J = 9.9, 4.2 $\mathrm{Hz}, 1 \mathrm{H}, \mathrm{CH}), 3.36\left(\mathrm{dd}, \mathrm{J}=14.0,4.2 \mathrm{~Hz}, 1 \mathrm{H}, \mathrm{CH}_{2}\right), 2.94\left(\mathrm{dd}, \mathrm{J}=14.0,9.9 \mathrm{~Hz}, 1 \mathrm{H}, \mathrm{CH}_{2}\right), 2.29$ 
(s, $\left.3 \mathrm{H}, \mathrm{CH}_{3}\right)$. Anal. Calcd. for $\mathrm{C}_{16} \mathrm{H}_{15} \mathrm{~N}_{3} \mathrm{O}_{2} \mathrm{~S}$ : C, 61.32; H, 4.82; N, 13.41. Found: $\mathrm{C}, 61.45 ; \mathrm{H}$, $4.74 ; \mathrm{N}, 13.50$.

5-(4-Ethylbenzyl)-2-(furan-2-ylmethylenehydrazono)thiazolidin-4-one (6b). Yield $79 \%, \mathrm{mp}=235-236^{\circ} \mathrm{C} .{ }^{1} \mathrm{H}-\mathrm{NMR}(400 \mathrm{MHz}, \mathrm{DMSO}) \delta 11.93(\mathrm{~s}, 1 \mathrm{H}, \mathrm{NH}), 8.19(\mathrm{~s}, 1 \mathrm{H}, \mathrm{CH}=)$, $7.83\left(\mathrm{~d}, \mathrm{~J}=0.9 \mathrm{~Hz}, 1 \mathrm{H}\right.$, furane), $7.18\left(\mathrm{~d}, \mathrm{~J}=8.2 \mathrm{~Hz}, 1 \mathrm{H}, \mathrm{C}_{6} \mathrm{H}_{4}\right), 7.15\left(\mathrm{~d}, \mathrm{~J}=8.3 \mathrm{~Hz}, 1 \mathrm{H}, \mathrm{C}_{6} \mathrm{H}_{4}\right)$, $6.93(\mathrm{~d}, \mathrm{~J}=3.4 \mathrm{~Hz}, 1 \mathrm{H}$, furane), $6.62(\mathrm{dd}, \mathrm{J}=3.3,1.8 \mathrm{~Hz}, 1 \mathrm{H}$ furane), $4.58(\mathrm{dd}, \mathrm{J}=9.7,4.2 \mathrm{~Hz}$, 1H, CH), 3.34 (dd, J = 14.1, 4.1 Hz, 1H, $\left.\mathrm{CH}_{2}\right), 2.96\left(\mathrm{dd}, \mathrm{J}=14.0,9.8 \mathrm{~Hz}, 1 \mathrm{H}, \mathrm{CH}_{2}\right), 2.58$ (q, J $\left.=7.6 \mathrm{~Hz}, 2 \mathrm{H}, \mathrm{CH}_{3} \underline{\mathrm{CH}_{2}}\right), 1.17$ (t, J = 7.6 Hz, 3H, $\underline{\mathrm{CH}_{3}} \mathrm{CH}_{2}$ ). Anal. Calcd. for $\mathrm{C}_{17} \mathrm{H}_{17} \mathrm{~N}_{3} \mathrm{O}_{2} \mathrm{~S}: \mathrm{C}$, 62.37; H, 5.23; N, 12.83. Found: C, 62.42; H, 5.2317; N, 12.92.

5-(2-Chlorobenzyl)-2-(furan-2-ylmethylenehydrazono)thiazolidin-4-one (6c). Yield 77\%, mp $=245-246^{\circ} \mathrm{C} .{ }^{1} \mathrm{H}-\mathrm{NMR}(400 \mathrm{MHz}, \mathrm{DMSO}) \delta 12.07(\mathrm{~s}, 1 \mathrm{H}, \mathrm{NH}), 8.21(\mathrm{~s}, 1 \mathrm{H}$, $\mathrm{CH}=), 7.84\left(\mathrm{~d}, \mathrm{~J}=1.5 \mathrm{~Hz}, 1 \mathrm{H}\right.$, furane), $7.49-7.46\left(\mathrm{~m}, 1 \mathrm{H}, \mathrm{C}_{6} \mathrm{H}_{4}\right), 7.42-7.39\left(\mathrm{~m}, 1 \mathrm{H}, \mathrm{C}_{6} \mathrm{H}_{4}\right)$, $7.38-7.29\left(\mathrm{~m}, 2 \mathrm{H}, \mathrm{C}_{6} \mathrm{H}_{4}\right), 6.95(\mathrm{~d}, \mathrm{~J}=3.4 \mathrm{~Hz}, 1 \mathrm{H}$, furane), $6.63(\mathrm{dd}, \mathrm{J}=3.4,1.8 \mathrm{~Hz}, 1 \mathrm{H}$, furane), $4.61(\mathrm{dd}, \mathrm{J}=10.2,4.5 \mathrm{~Hz}, 1 \mathrm{H}, \mathrm{CH}), 3.58\left(\mathrm{dd}, \mathrm{J}=14.2,4.5 \mathrm{~Hz}, 1 \mathrm{H}, \mathrm{CH}_{2}\right), 3.10$ (dd, J $=14.2,10.2 \mathrm{~Hz}, 1 \mathrm{H}, \mathrm{CH}_{2}$ ). Anal. Calcd. for $\mathrm{C}_{15} \mathrm{H}_{12} \mathrm{ClN}_{3} \mathrm{O}_{2} \mathrm{~S}: \mathrm{C}, 53.97 ; \mathrm{H}, 3.62 ; \mathrm{N}, 12.59$. Found: C, 53.85; H, 3.69; N, 12.49 .

5-(4-Chlorobenzyl)-2-(furan-2-ylmethylenehydrazono)thiazolidin-4-one

(6d). Yield 85\%, mp $=239-240^{\circ} \mathrm{C} .{ }^{1} \mathrm{H}-\mathrm{NMR}(400 \mathrm{MHz}, \mathrm{DMSO}) \delta 11.97(\mathrm{~s}, 1 \mathrm{H}, \mathrm{NH}), 8.19(\mathrm{~s}, 1 \mathrm{H}$, $\mathrm{CH}=), 7.84\left(\mathrm{~d}, \mathrm{~J}=1.4 \mathrm{~Hz}, 1 \mathrm{H}\right.$, furane), $7.38\left(\mathrm{~d}, \mathrm{~J}=8.3 \mathrm{~Hz}, 2 \mathrm{H}, \mathrm{C}_{6} \mathrm{H}_{4}\right), 7.30(\mathrm{~d}, \mathrm{~J}=8.4 \mathrm{~Hz}, 2 \mathrm{H}$, $\left.\mathrm{C}_{6} \mathrm{H}_{4}\right), 6.94(\mathrm{~d}, \mathrm{~J}=3.4 \mathrm{~Hz}, 1 \mathrm{H}$, furane), $6.63(\mathrm{dd}, \mathrm{J}=3.4,1.8 \mathrm{~Hz}, 1 \mathrm{H}$, furane), 4.62 (dd, J = 9.1, $4.5 \mathrm{~Hz}, 1 \mathrm{H}, \mathrm{CH}), 3.35$ (dd, J = 13.3, $3.5 \mathrm{~Hz}, 1 \mathrm{H}, \mathrm{CH}_{2}$ ), 3.05 (dd, J = 14.1, 9.2 Hz, 1H, $\mathrm{CH}_{2}$ ). Anal. Calcd. for $\mathrm{C}_{15} \mathrm{H}_{12} \mathrm{ClN}_{3} \mathrm{O}_{2} \mathrm{~S}$ : C, 53.97; H, 3.62; N, 12.59. Found: C, 53.81; H, 3.6955; N, 12.64.

5-(2,4-Dichlorobenzyl)-2-(furan-2-ylmethylenehydrazono)thiazolidin-4-one (6e). Yield 87\%, mp $=258-259^{\circ} \mathrm{C} .{ }^{1} \mathrm{H}-\mathrm{NMR}(400 \mathrm{MHz}, \mathrm{DMSO}) \delta 12.11(\mathrm{~s}, 1 \mathrm{H}, \mathrm{NH}), 8.21(\mathrm{~s}, 1 \mathrm{H}$, $\mathrm{CH}=), 7.87-7.84\left(\mathrm{~m}, 1 \mathrm{H}\right.$, furane), $7.66-7.63\left(\mathrm{~m}, 1 \mathrm{H}, \mathrm{C}_{6} \mathrm{H}_{3}\right), 7.47-7.40\left(\mathrm{~m}, 2 \mathrm{H}, \mathrm{C}_{6} \mathrm{H}_{3}\right), 6.95$ (d, J = 3.5 Hz, 1H, furane), 6.64 (dd, J = 3.4, 1.8 Hz, 1H, furane), 4.60 (dd, J = 9.9, $4.8 \mathrm{~Hz}, 1 \mathrm{H}$, $\mathrm{CH}), 3.53\left(\mathrm{dd}, \mathrm{J}=14.2,4.8 \mathrm{~Hz}, 1 \mathrm{H}, \mathrm{CH}_{2}\right), 3.13\left(\mathrm{dd}, \mathrm{J}=14.2,9.9 \mathrm{~Hz}, 1 \mathrm{H}, \mathrm{CH}_{2}\right)$. Anal. Calcd. for $\mathrm{C}_{15} \mathrm{H}_{11} \mathrm{Cl}_{2} \mathrm{~N}_{3} \mathrm{O}_{2} \mathrm{~S}$ : C, 48.93; H, 3.01; N, 11.41. Found: C, 49.04; H, 2.95; N, 11.52.

5-(2,5-Dichlorobenzyl)-2-(furan-2-ylmethylene-hydrazono)thiazolidin-4-one (6f). Yield 74\%, mp $=241-242^{\circ} \mathrm{C} .{ }^{1} \mathrm{H}-\mathrm{NMR}(400 \mathrm{MHz}, \mathrm{DMSO}) \delta 12.12(\mathrm{~s}, 1 \mathrm{H}), 8.22(\mathrm{~s}, 1 \mathrm{H}), 7.88$ $-7.83\left(\mathrm{~m}, 1 \mathrm{H}\right.$, furane), $7.52\left(\mathrm{~d}, \mathrm{~J}=5.9 \mathrm{~Hz}, 1 \mathrm{H}, \mathrm{C}_{6} \mathrm{H}_{3}\right), 7.51$ (s, $\left.1 \mathrm{H}, \mathrm{C}_{6} \mathrm{H}_{3}\right), 7.41$ (dd, J = 8.6, $\left.2.6 \mathrm{~Hz}, 1 \mathrm{H}, \mathrm{C}_{6} \mathrm{H}_{3}\right), 6.96(\mathrm{~d}, \mathrm{~J}=3.4 \mathrm{~Hz}, 1 \mathrm{H}$, furane), $6.63(\mathrm{dd}, \mathrm{J}=3.4,1.8 \mathrm{~Hz}, 1 \mathrm{H}$, furane), 4.65 $(\mathrm{dd}, \mathrm{J}=9.9,4.9 \mathrm{~Hz}, 1 \mathrm{H}, \mathrm{CH}), 3.53\left(\mathrm{dd}, \mathrm{J}=14.2,4.9 \mathrm{~Hz}, 1 \mathrm{H}, \mathrm{CH}_{2}\right), 3.15(\mathrm{dd}, \mathrm{J}=14.2,9.9 \mathrm{~Hz}$, $1 \mathrm{H}, \mathrm{CH}_{2}$ ). Anal. Calcd. for $\mathrm{C}_{15} \mathrm{H}_{11} \mathrm{Cl}_{2} \mathrm{~N}_{3} \mathrm{O}_{2} \mathrm{~S}$ : C, 48.93; H, 3.01; N, 11.41. Found: $\mathrm{C}, 49.06 ; \mathrm{H}$, 3.9508; N, 11.35 .

2-(Furan-2-ylmethylene-hydrazono)-5-(4-methoxy-benzyl)thiazolidin-4-one (6g). Yield 81\%, mp $=224-225^{\circ} \mathrm{C} .{ }^{1} \mathrm{H}-\mathrm{NMR}(400 \mathrm{MHz}, \mathrm{DMSO}) \delta 11.93(\mathrm{~s}, 1 \mathrm{H}, \mathrm{NH}), 8.18(\mathrm{~s}, 1 \mathrm{H}$, $\mathrm{CH}=), 7.84(\mathrm{~d}, \mathrm{~J}=1.7 \mathrm{~Hz}, 1 \mathrm{H}$, furane), $7.18(\mathrm{~d}, \mathrm{~J}=11.8 \mathrm{~Hz}, 1 \mathrm{H}), 6.95-6.92$ (m, 1H, furane), $6.87\left(\mathrm{~d}, \mathrm{~J}=11.7 \mathrm{~Hz}, 2 \mathrm{H}, \mathrm{C}_{6} \mathrm{H}_{4}\right), 6.63(\mathrm{dd}, \mathrm{J}=3.4,1.8 \mathrm{~Hz}, 1 \mathrm{H}$, furane), $4.56(\mathrm{dd}, \mathrm{J}=9.4,4.3$ $\mathrm{Hz}, 1 \mathrm{H}, \mathrm{CH}), 3.73$ (s, 1H, $\mathrm{CH}_{3} \mathrm{O}$ ), $3.32-3.27\left(\mathrm{~m}, 1 \mathrm{H}, \mathrm{CH}_{2}\right), 2.95$ (dd, J = 14.1, $9.4 \mathrm{~Hz}, 1 \mathrm{H}$, $\mathrm{CH}_{2}$ ). Anal. Calcd. for $\mathrm{C}_{16} \mathrm{H}_{15} \mathrm{~N}_{3} \mathrm{O}_{3} \mathrm{~S}: \mathrm{C}, 58.35 ; \mathrm{H}, 4.59$; N, 12.76. Found: $\mathrm{C}, 58.42 ; \mathrm{H}, 4.64$; N, 12.69 .

5-(2-Methylbenzyl)-2-(thiophen-2-ylmethylenehydrazono)thiazolidin-4-one (7a). Yield 71\%, mp $=263-264{ }^{\circ} \mathrm{C} .{ }^{1} \mathrm{H}-\mathrm{NMR}(400 \mathrm{MHz}, \mathrm{DMSO}) \delta 11.97(\mathrm{~s}, 1 \mathrm{H}), 8.53(\mathrm{~s}, 1 \mathrm{H}), 7.65$ $\left(\mathrm{d}, \mathrm{J}=5.0 \mathrm{~Hz}, 1 \mathrm{H}\right.$, thiophene), $7.48\left(\mathrm{~d}, \mathrm{~J}=3.3 \mathrm{~Hz}, 1 \mathrm{H}, \mathrm{C}_{6} \mathrm{H}_{4}\right), 7.27-7.10\left(\mathrm{~m}, 5 \mathrm{H}, \mathrm{C}_{6} \mathrm{H}_{4}+\right.$ 
thiophene), 4.58 (dd, J = 10.7, 4.0 Hz, 1H, CH), 3.47 (dd, J = 14.6, 3.9 Hz, 1H, CH2), 2.97 (dd, $\left.\mathrm{J}=14.4,11.0 \mathrm{~Hz}, 1 \mathrm{H}, \mathrm{CH}_{2}\right), 2.31\left(\mathrm{~s}, 3 \mathrm{H}, \mathrm{CH}_{3}\right)$. Anal. Calcd. for $\mathrm{C}_{16} \mathrm{H}_{15} \mathrm{~N}_{3} \mathrm{OS}_{2}: \mathrm{C}, 58.33 ; \mathrm{H}$, 4.59; N, 12.76. Found: C, 58.42; H, 4.64; N, 12.69.

5-(3-Methylbenzyl)-2-(thiophen-2-ylmethylenehydrazono)thiazolidin-4-one (7b). Yield 78\%, mp $=236-237^{\circ} \mathrm{C} .{ }^{1} \mathrm{H}-\mathrm{NMR}(400 \mathrm{MHz}, \mathrm{DMSO}) \delta 11.92(\mathrm{~s}, 1 \mathrm{H}, \mathrm{NH}), 8.51(\mathrm{~s}, 1 \mathrm{H}$, $\mathrm{CH}=), 7.65(\mathrm{~d}, \mathrm{~J}=5.0 \mathrm{~Hz}, 1 \mathrm{H}$, thiophene), $7.47(\mathrm{~d}, \mathrm{~J}=3.4 \mathrm{~Hz}, 1 \mathrm{H}$, thiophene), $7.21(\mathrm{t}, \mathrm{J}=7.5$ $\left.\mathrm{Hz}, 1 \mathrm{H}, \mathrm{C}_{6} \mathrm{H}_{4}\right), 7.13\left(\mathrm{dd}, \mathrm{J}=4.9,3.7 \mathrm{~Hz}, 1 \mathrm{H}\right.$, thiophene), $7.11-7.04\left(\mathrm{~m}, 3 \mathrm{H}, \mathrm{C}_{6} \mathrm{H}_{4}\right), 4.60$ (dd, $\mathrm{J}=9.9,4.1 \mathrm{~Hz}, 1 \mathrm{H}, \mathrm{CH}), 3.37\left(\mathrm{dd}, \mathrm{J}=14.1,4.1 \mathrm{~Hz}, 1 \mathrm{H}, \mathrm{CH}_{2}\right), 2.96(\mathrm{dd}, \mathrm{J}=14.1,10.0 \mathrm{~Hz}, 1 \mathrm{H}$, $\mathrm{CH}_{2}$ ), 2.29 (s, 3H, $\mathrm{CH}_{3}$ ). Anal. Calcd. for $\mathrm{C}_{16} \mathrm{H}_{15} \mathrm{~N}_{3} \mathrm{OS}_{2}$ : C, 58.33; H, 4.59; N, 12.76. Found: C, 58.27; H, 4.51; N, 12.65.

5-(4-Ethylbenzyl)-2-(thiophen-2-ylmethylenehydrazono)thiazolidin-4-one (7c). Yield $83 \%, \mathrm{mp}=241-242^{\circ} \mathrm{C} .{ }^{1} \mathrm{H}-\mathrm{NMR}(400 \mathrm{MHz}, \mathrm{DMSO}) \delta 11.94(\mathrm{~s}, 1 \mathrm{H}, \mathrm{NH}), 8.51(\mathrm{~s}, 1 \mathrm{H}$, $\mathrm{CH}=), 7.66(\mathrm{~d}, \mathrm{~J}=5.0 \mathrm{~Hz}, 1 \mathrm{H}$, thiophene), $7.48(\mathrm{~d}, \mathrm{~J}=3.1 \mathrm{~Hz}, 1 \mathrm{H}$, thiophene), $7.22-7.09(\mathrm{~m}$, $5 \mathrm{H}, \mathrm{C}_{6} \mathrm{H}_{4}+$ thiophene), $4.59(\mathrm{dd}, \mathrm{J}=9.7,4.1 \mathrm{~Hz}, 1 \mathrm{H}, \mathrm{CH}), 3.35(\mathrm{dd}, \mathrm{J}=14.2,4.1 \mathrm{~Hz}, 1 \mathrm{H}$, $\mathrm{CH}_{2}$ ), 2.97 (dd, J = 14.1, $\left.9.8 \mathrm{~Hz}, 1 \mathrm{H}, \mathrm{CH}_{2}\right), 2.58$ (q, J = 7.6 Hz, 2H, $\mathrm{CH}_{3} \underline{\mathrm{CH}_{2}}$ ), 1.17 (t, J = 7.6 $\mathrm{Hz}, 3 \mathrm{H}, \underline{\mathrm{CH}_{3}} \mathrm{CH}_{2}$ ). Anal. Calcd. for $\mathrm{C}_{17} \mathrm{H}_{17} \mathrm{~N}_{3} \mathrm{OS}_{2}$ : C, 59.45; H, 4.99; N, 12.23. Found: C, 59.57; $\mathrm{H}, 4.89 ; \mathrm{N}, 12.31$.

\section{5-(4-Isopropylbenzyl)-2-(thiophen-2-ylmethylenehydrazono)thiazolidin-4-one} (7d). Yield 85\%, mp $=225-226^{\circ} \mathrm{C} .{ }^{1} \mathrm{H}-\mathrm{NMR}(400 \mathrm{MHz}, \mathrm{DMSO}) \delta 11.95(\mathrm{~s}, 1 \mathrm{H}, \mathrm{NH}), 8.52(\mathrm{~s}$, $1 \mathrm{H}, \mathrm{CH}=), 7.66(\mathrm{~d}, \mathrm{~J}=5.0 \mathrm{~Hz}, 1 \mathrm{H}$, thiophene), $7.48(\mathrm{~d}, \mathrm{~J}=3.4 \mathrm{~Hz}, 1 \mathrm{H}$, thiophene), $7.20(\mathrm{~s}, 4 \mathrm{H}$, $\left.\mathrm{C}_{6} \mathrm{H}_{4}\right), 7.16-7.11(\mathrm{~m}, 1 \mathrm{H}$, thiophene), $4.59(\mathrm{dd}, \mathrm{J}=9.9,4.0 \mathrm{~Hz}, 1 \mathrm{H}, \mathrm{CH}), 3.36(\mathrm{dd}, \mathrm{J}=14.2$, $\left.4.1 \mathrm{~Hz}, 1 \mathrm{H}, \mathrm{CH}_{2}\right), 3.01-2.82\left(\mathrm{~m}, 1 \mathrm{H} \mathrm{CH}_{2}+\left(\mathrm{CH}_{3}\right)_{2} \underline{\mathrm{CH}}\right), 1.19\left(\mathrm{~d}, \mathrm{~J}=6.9 \mathrm{~Hz}, 6 \mathrm{H},\left(\underline{\mathrm{CH}_{3}}\right)_{2} \mathrm{CH}\right)$. Anal. Calcd. for $\mathrm{C}_{18} \mathrm{H}_{19} \mathrm{~N}_{3} \mathrm{OSS}_{2}$ : C, 60.48; H, 5.36; N, 11.75. Found: $\mathrm{C}, 60.53 ; \mathrm{H}, 5.29 ; \mathrm{N}, 11.67$.

5-(3-Chlorobenzyl)-2-(thiophen-2-ylmethylenehydrazono)thiazolidin-4-one (7e). Yield 75\%, mp $=224-225^{\circ} \mathrm{C} .{ }^{1} \mathrm{H}-\mathrm{NMR}(400 \mathrm{MHz}, \mathrm{DMSO}) \delta 12.01(\mathrm{~s}, 1 \mathrm{H}, \mathrm{NH}), 8.52(\mathrm{~s}, 1 \mathrm{H}$, $\mathrm{CH}=), 7.48\left(\mathrm{~d}, \mathrm{~J}=2.8 \mathrm{~Hz}, 1 \mathrm{H}\right.$, thiophene), $7.40-7.31\left(\mathrm{~m}, 4 \mathrm{H}, \mathrm{C}_{6} \mathrm{H}_{4}\right), 7.26(\mathrm{~d}, \mathrm{~J}=7.2 \mathrm{~Hz}, 1 \mathrm{H}$, thiophene), 7.14 (dd, J = 5.0, 3.6 Hz, 1H, thiophene), 4.67 (dd, J = 9.3, 4.5 Hz, 1H, CH), 3.38 $\left(\mathrm{dd}, \mathrm{J}=14.2,4.5 \mathrm{~Hz}, 1 \mathrm{H}, \mathrm{CH}_{2}\right), 3.06\left(\mathrm{dd}, \mathrm{J}=14.2,9.4 \mathrm{~Hz}, 1 \mathrm{H}, \mathrm{CH}_{2}\right)$. Anal. Calcd. for $\mathrm{C}_{15} \mathrm{H}_{12} \mathrm{ClN}_{3} \mathrm{OS}_{2}$ : C, 51.50; H, 3.46; N, 12.01. Found: C, 51.62; H, 3.51; N, 12.07.

5-(4-Chlorobenzyl)-2-(thiophen-2-ylmethylenehydrazono)thiazolidin-4-one (7f). Yield $87 \%, \mathrm{mp}=257-258^{\circ} \mathrm{C} .{ }^{1} \mathrm{H}-\mathrm{NMR}(400 \mathrm{MHz}, \mathrm{DMSO}) \delta 11.95(\mathrm{~s}, 1 \mathrm{H}, \mathrm{NH}), 8.51(\mathrm{~s}, 1 \mathrm{H}$, $\mathrm{CH}=), 7.66(\mathrm{~d}, \mathrm{~J}=4.7 \mathrm{~Hz}, 1 \mathrm{H}$, thiophene), $7.48(\mathrm{~d}, \mathrm{~J}=3.1 \mathrm{~Hz}, 1 \mathrm{H}$, thiophene), 7.39 (d, J = 8.3 $\left.\mathrm{Hz}, 2 \mathrm{H}, \mathrm{C}_{6} \mathrm{H}_{4}\right), 7.31$ (d, J = 8.3 Hz, 2H, $\left.\mathrm{C}_{6} \mathrm{H}_{4}\right), 7.16-7.11(\mathrm{~m}, 1 \mathrm{H}$, thiophene), 4.62 (dd, J = 9.0, 4.3 Hz, 1H, CH), $3.36\left(\mathrm{dd}, \mathrm{J}=14.2,4.4 \mathrm{~Hz}, 1 \mathrm{H}, \mathrm{CH}_{2}\right), 3.06(\mathrm{dd}, \mathrm{J}=14.1,9.3 \mathrm{~Hz}, 1 \mathrm{H}$, $\mathrm{CH}_{2}$ ). Anal. Calcd. for $\mathrm{C}_{15} \mathrm{H}_{12} \mathrm{ClN}_{3} \mathrm{OS}_{2}: \mathrm{C}, 51.50 ; \mathrm{H}, 3.46 ; \mathrm{N}, 12.01$. Found: C, 51.39; H, 3.53; N, 12.09 .

5-(3,4-Dichlorobenzyl)-2-(thiophen-2-ylmethylenehydrazono)thiazolidin-4-one (7g). Yield 74\%, mp = 245-246 ${ }^{\circ} \mathrm{C} .{ }^{1} \mathrm{H}-\mathrm{NMR}(400 \mathrm{MHz}, \mathrm{DMSO}) \delta 12.01(\mathrm{~s}, 1 \mathrm{H}, \mathrm{NH}), 8.52(\mathrm{~s}$, $1 \mathrm{H}, \mathrm{CH}=), 7.67\left(\mathrm{~d}, \mathrm{~J}=5.0 \mathrm{~Hz}, 1 \mathrm{H}, \mathrm{C}_{6} \mathrm{H}_{3}\right), 7.61-7.57\left(\mathrm{~m}, 2 \mathrm{H}, \mathrm{C}_{6} \mathrm{H}_{3}\right), 7.50-7.47(\mathrm{~m}, 1 \mathrm{H}$, thiophene), 7.29 (dd, J = 8.3, 2.0 Hz, $1 \mathrm{H}$, thiophene), $7.14(\mathrm{dd}, \mathrm{J}=5.0,3.6 \mathrm{~Hz}, 1 \mathrm{H}$, thiophene), 4.67 (dd, J = 8.9, $4.7 \mathrm{~Hz}, 1 \mathrm{H}, \mathrm{CH}$ ), 3.36 (dd, J = 14.2, 4.7 Hz, 1H, $\mathrm{CH}_{2}$ ), 3.09 (dd, J = 14.2, 9.0 $\mathrm{Hz}, 1 \mathrm{H}, \mathrm{CH}_{2}$ ). Anal. Calcd. for $\mathrm{C}_{15} \mathrm{H}_{11} \mathrm{Cl}_{2} \mathrm{~N}_{3} \mathrm{OS}_{2}$ : C, 46.88; H, 2.89; N, 10.93. Found: C, 46.97; $\mathrm{H}, 2.81 ; \mathrm{N}, 10.82$.

\section{5-(4-Methoxybenzyl)-2-(thiophen-2-ylmethylenehydrazono)thiazolidin-4-one}

(7h). Yield 82\%, mp $=221-222^{\circ} \mathrm{C} .{ }^{1} \mathrm{H}-\mathrm{NMR}(400 \mathrm{MHz}, \mathrm{DMSO}) \delta 11.90$ (s, 1H, NH), 8.51 (s, $1 \mathrm{H}, \mathrm{CH}=), 7.66(\mathrm{~d}, \mathrm{~J}=5.0 \mathrm{~Hz}, 1 \mathrm{H}$, thiophene), 7.47 (d, J = 3.4 Hz, 1H, thiophene), 7.19 (d, J 
$\left.=8.5 \mathrm{~Hz}, 2 \mathrm{H}, \mathrm{C}_{6} \mathrm{H}_{4}\right), 7.16-7.11\left(\mathrm{~m}, 1 \mathrm{H}\right.$, thiophene), $6.88\left(\mathrm{~d}, \mathrm{~J}=8.5 \mathrm{~Hz}, 2 \mathrm{H}, \mathrm{C}_{6} \mathrm{H}_{4}\right), 4.56(\mathrm{dd}$, $\mathrm{J}=9.4,4.2 \mathrm{~Hz}, 1 \mathrm{H}, \mathrm{CH}), 3.73(\mathrm{~s}, 3 \mathrm{H}), 3.31\left(\mathrm{dd}, \mathrm{J}=13.9,3.9 \mathrm{~Hz}, 1 \mathrm{H}, \mathrm{CH}_{2}\right), 2.96(\mathrm{dd}, \mathrm{J}=14.2$, $9.4 \mathrm{~Hz}, 1 \mathrm{H}, \mathrm{CH}_{2}$ ). Anal. Calcd. for $\mathrm{C}_{16} \mathrm{H}_{15} \mathrm{~N}_{3} \mathrm{O}_{2} \mathrm{~S}_{2}$ : C, 55.63; H, 4.38; N, 12.16. Found: C, $55.6375 ; \mathrm{H}, 4.45 ; \mathrm{N}, 12.03$.

2-(Thiophen-2-ylmethylenehydrazono)-5-(3-trifluoromethyl-benzyl thiazolidin-4one (7i). Yield 77\%, mp $=221-222^{\circ} \mathrm{C} .{ }^{1} \mathrm{H}-\mathrm{NMR}(400 \mathrm{MHz}, \mathrm{DMSO}) \delta 12.02(\mathrm{~s}, 1 \mathrm{H}, \mathrm{NH}), 8.52$ (s, $1 \mathrm{H}, \mathrm{CH}=), 7.69-7.54\left(\mathrm{~m}, 5 \mathrm{H}, \mathrm{C}_{6} \mathrm{H}_{4}+\right.$ thiophene), $7.50-7.46(\mathrm{~m}, 1 \mathrm{H}$, thiophene), 7.13 (dd, $\mathrm{J}=5.0,3.6 \mathrm{~Hz}, 1 \mathrm{H}$, thiophene), $4.72(\mathrm{dd}, \mathrm{J}=9.0,4.6 \mathrm{~Hz}, 1 \mathrm{H}, \mathrm{CH}), 3.46(\mathrm{dd}, \mathrm{J}=14.2,4.6 \mathrm{~Hz}$, $1 \mathrm{H}, \mathrm{CH} 2), 3.19$ (dd, $\mathrm{J}=14.2,9.1 \mathrm{~Hz}, 1 \mathrm{H}, \mathrm{CH}_{2}$ ). Anal. Calcd. for $\mathrm{C}_{16} \mathrm{H}_{12} \mathrm{~F}_{3} \mathrm{~N}_{3} \mathrm{OS}_{2}: \mathrm{C}, 50.12 ; \mathrm{H}$, 3.15 ; N, 10.96. Found: C, 50.01; H, 3.1523; N, 10.87 .

\subsection{Molecular docking.}

The molecular docking for the synthesized compounds (6a-g) and (7a-i) was performed against the receptor GlcN-6P (PDB: 2VF5) to assess the extent of H-bonding and the binding affinities. The software ChemDraw Ultra12.0 design the structures, Aautodock-tools 1.5.6 to produce PDBQTs, Autodock-vina to produce a docked file, and Pymol to produce docked images were employed in the study. The PDBs for the ligands were obtained from the online smiles translator (https://cactus.nci.nih.gov/translate/).

\subsection{Pharmacology.}

2.4.1. Antibacterial data collection to signify bacterial strains and growth conditions.

Inhibition of bacterial growth was determined by measuring the absorbance at $600 \mathrm{~nm}$ (OD600), using a Tecan M1000 Pro monochromator plate reader. The percentage of growth inhibition was calculated for each of them, using the negative control (media only) and positive control (bacteria without inhibitors) at the same time as references.

\subsubsection{Antifungal data collection.}

The growth inhibition of $C$. albicans was determined by measuring the absorbance at $530 \mathrm{~nm}$ (OD530), while the growth inhibition of $C$. neoformans was determined by measuring the difference in absorbance between 600 and $570 \mathrm{~nm}$ (OD600-570), after the addition of resazurin $\left(0.001 \%\right.$ final concentration) and incubation at $35{ }^{\circ} \mathrm{C}$ for additional $2 \mathrm{~h}$. The absorbance was measured using a Biotek Synergy HTX plate reader. The percentage of growth inhibition was calculated for each of them, using the negative control (media only) and positive control (fungal without inhibitors) at the same time as references.

\subsubsection{Inhibition.}

The percentage of growth inhibition of an individual sample was based on the negative controls (media only) and positive controls (bacterial/fungal media without inhibitors). Negative inhibition values indicated that the growth rate (or OD600) is higher than the negative control (Bacteria/fungi only, set to $0 \%$ inhibition). The growth rates for all the bacteria and fungi have a variation of $-/+10 \%$, which is within the reported normal distribution of bacterial/fungal growth (https://www.co-add.org).

\section{Results and Discussion}


3.1. Synthesis of 5-(4-substituted-benzyl)-2-(furan/thiophen-2-ylmethylene-hydrazono) thiazolidin-4-ones.

The starting reagents for the preparation of target compounds were ethyl 2-bromo-3aryl propanates $3 \mathrm{a}-\mathrm{m}$, which were synthesized by bromarylation of ethyl acrylate 2 using aryldiazonium salts 1 respective to the procedure described in [49]. It was found that on refluxing 3a-m in ethanol with thiosemicarbazones of furfural 4 and thiophene-2-carbaldehyde 5 yielded the 5-(4-R-benzyl)-2-(furan / thiophen-2-ylmethylenehydrazono) thiazolidine-4 they are 6a-i and 7a-i (Scheme 1).

The structures of the obtained compounds were confirmed by ${ }^{1} \mathrm{H}-\mathrm{NMR}$ spectroscopy and elemental analysis. In ${ }^{1} \mathrm{H}-\mathrm{NMR}$ spectra, signals for all the structural units' protons were observed in their characteristic ranges. In the region of a strong magnetic field, we observed three doublets of doublets, which is the characteristic of the ABX spin-spin system.

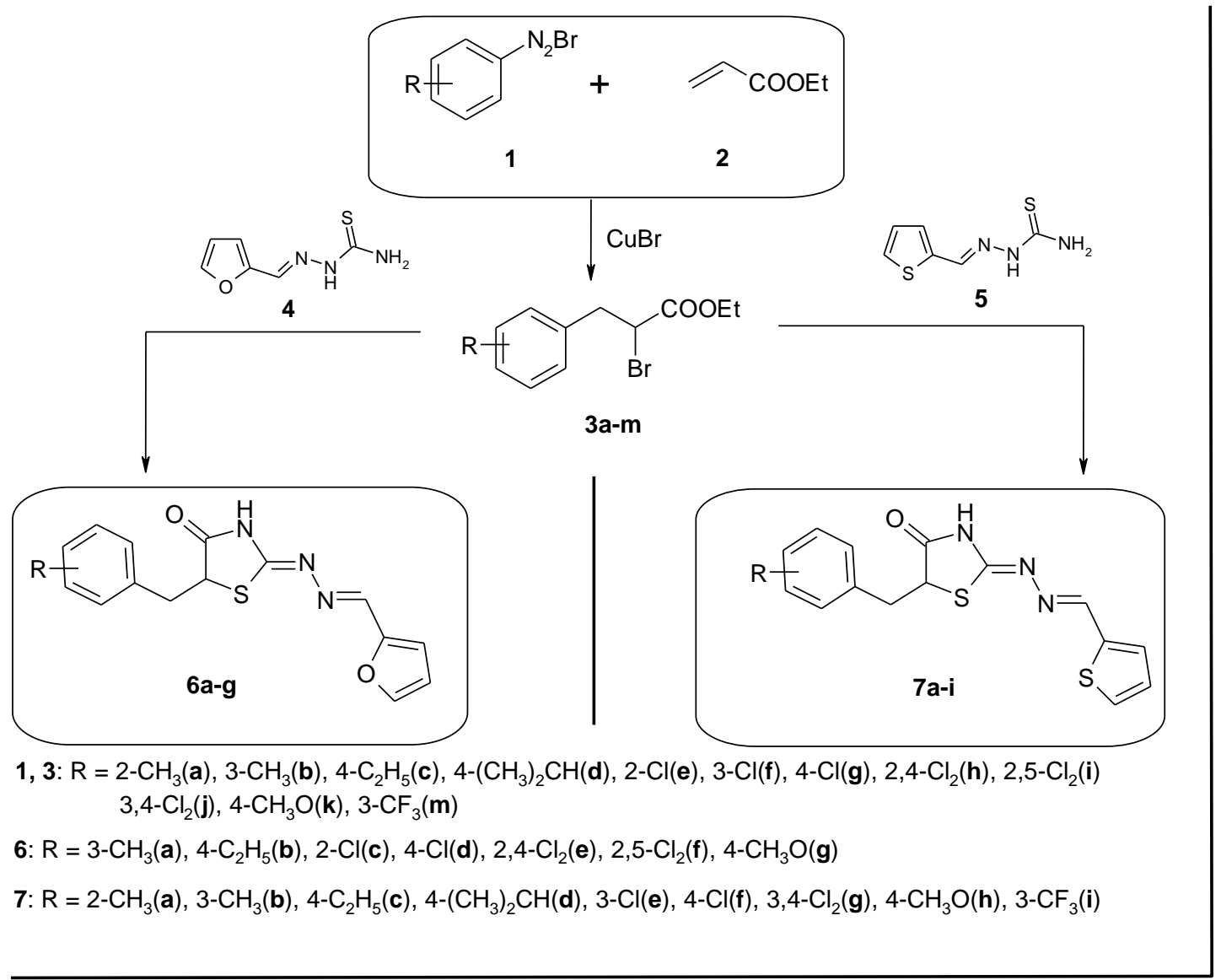

Scheme 1. Synthesis of 5-(4-substituted-benzyl)-2-(furan/thiophen-2-ylmethylene-hydrazono) thiazolidin-4ones.

\subsection{Molecular docking.}

The synthesized compounds (6a-g) and (7a-i) were subjected to molecular docking assessment using Aautodock-tools 1.5.6 tools against GlcN-6P as per the procedure mentioned [50-51]. The molecular docking findings revealed that some ligands have been observed to represent similar H-bonding with the amino acid residues like ASN522 (6a, 6b, 6e, 6f), ASP474 (6a, 6b), SER316 (6d, 6e), ASN261 (7b, 7e, 7f, 7g, 7h) SER328 (7c, 7d). The ligands (6a-g) and $(7 \mathrm{a}-\mathrm{i})$ represented the significant binding affinities in the range -6.9 to $-5.5 \mathrm{kcal} / \mathrm{mole}$ and 
-7.0 to $-5.2 \mathrm{kcal} / \mathrm{mole}$, respectively. While comparing the molecular docking findings and antimicrobial assessment, it was observed that there is strong agreement in both the findings.

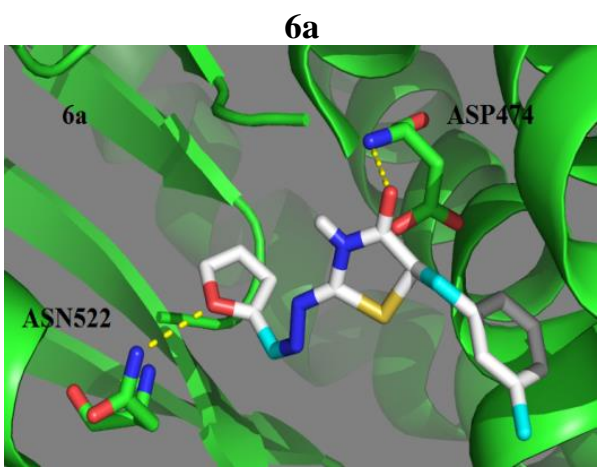

6c

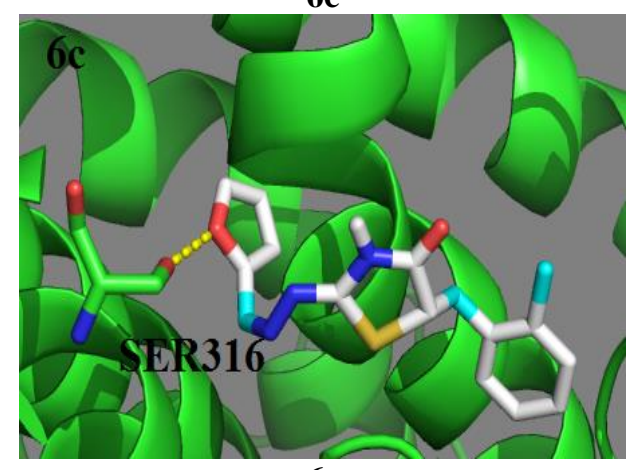

6e

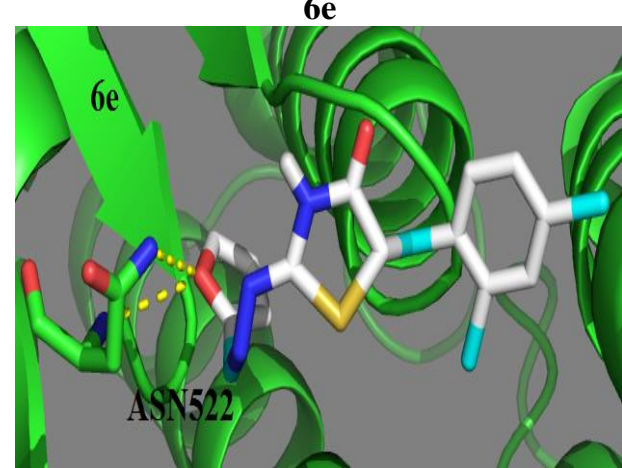

6b

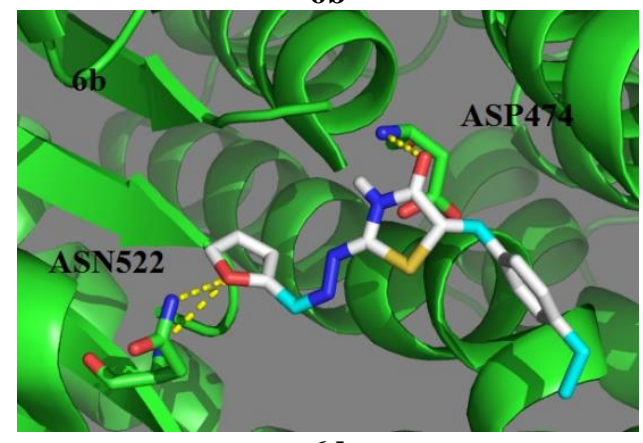

6d
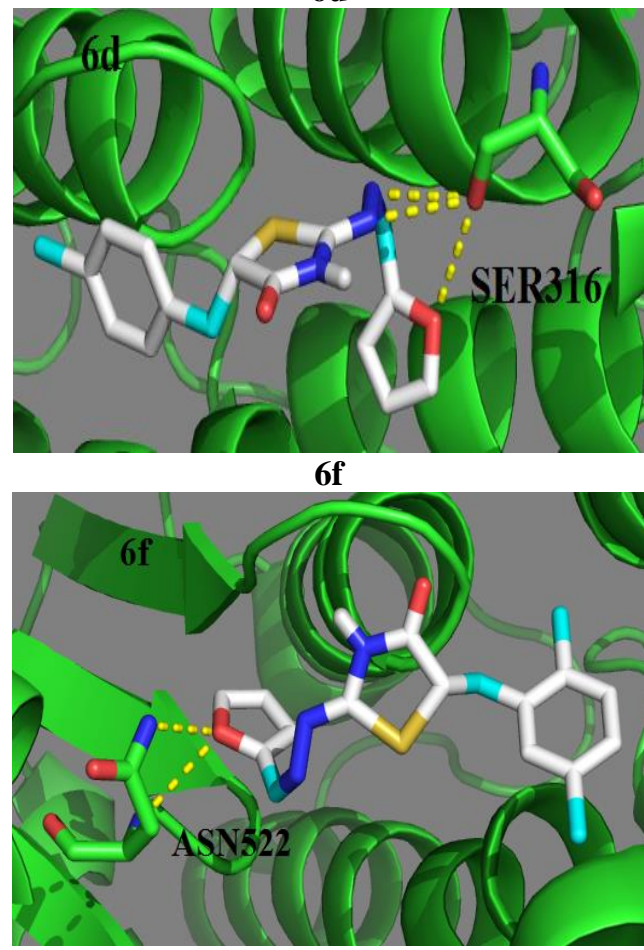

6g

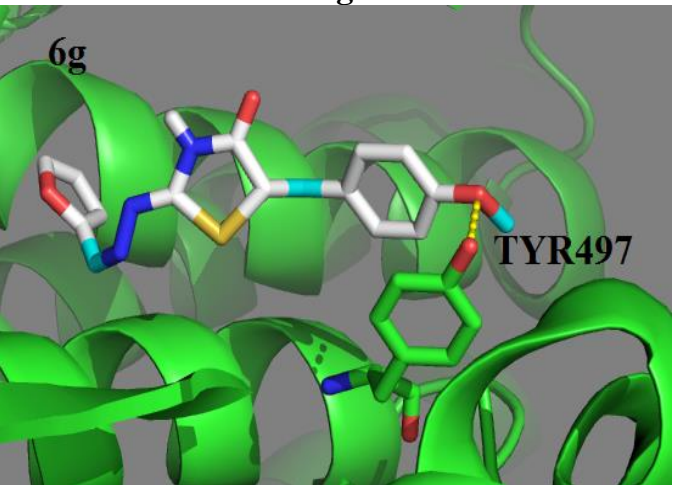

Figure 1. The docked images of the compounds (6a-g) against the receptor GlcN-6P (PDB: 2VF5).
$7 \mathbf{a}$

$7 \mathbf{b}$
$7 \mathbf{c}$ 

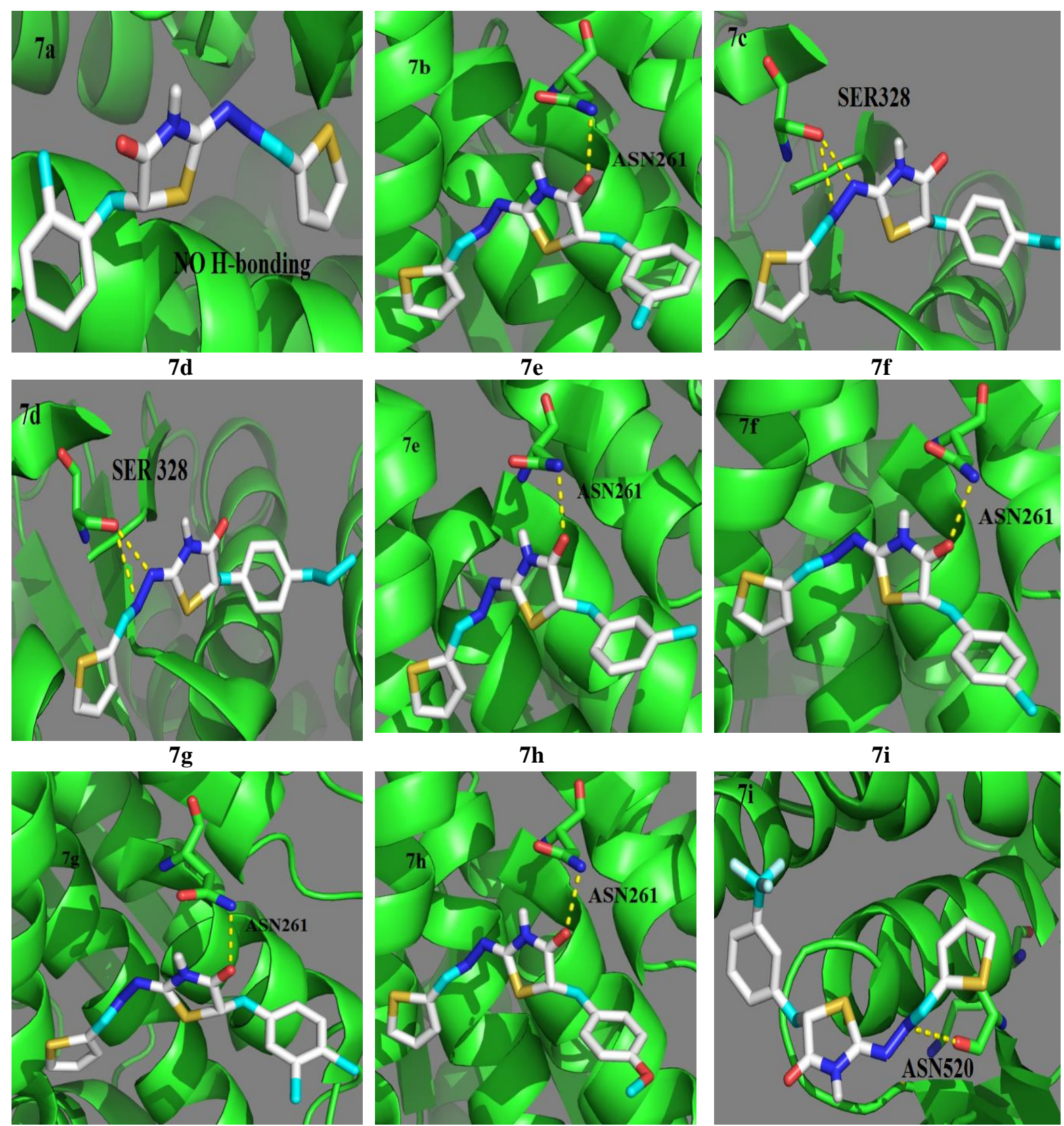

Figure 2. The docked images of the compouds (7a-i) against the receptor GlcN-6P (PDB: 2VF5).

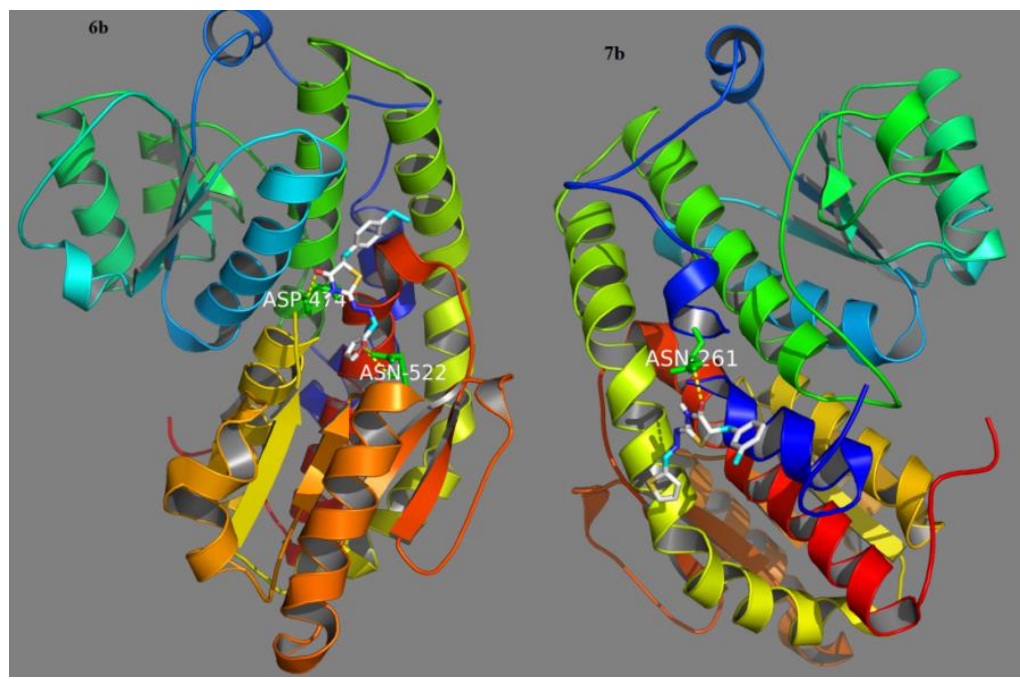

Figure 3. The docked images of the compounds ( $6 b$ \& $7 b)$ against the receptor GlcN-6P (PDB: 2VF5). 
The compounds $6 \mathrm{e}, 6 \mathrm{f}, 7 \mathrm{~g}$, and $7 \mathrm{f}$ have been found to exhibit significant antibacterial effects against $S$. aureus; simultaneously, these compounds were reported to represent the significant H-bonding. On the other hand, the compounds $6 \mathrm{a}, 6 \mathrm{e}, 6 \mathrm{f}, 7 \mathrm{~d}$, and $7 \mathrm{~g}$ have been observed to possess significant antifungal potential against $C$. albicans, and $C$. neoformans and at the same time represented the significant $H$-bonding. The detailed docked images and the binding affinities are represented in Figure 1, Figure 2, Figure 3 Table 1.

Table 1. Representing the Aminoacid residues of GlcN-6 involved in H-bonding, binding affinities, rmsd values of the compounds $(6 \mathrm{a}-\mathrm{g})$ and $(7 \mathrm{a}-\mathrm{i})$.

\begin{tabular}{l|l|c|c|c} 
S. No. & $\begin{array}{l}\text { Amino acid residues involved } \\
\text { in H-bonding }\end{array}$ & $\begin{array}{c}\text { Binding Affinity } \mathbf{( 9} \\
\text { Modes of binding) } \\
\text { Kcal/mole }\end{array}$ & $\begin{array}{c}\text { Distance from rmsd } \\
\text { (l. } \mathbf{b})\end{array}$ & $\begin{array}{c}\text { Distance from rmsd } \\
\text { (u. } \mathbf{b})\end{array}$ \\
\hline $\mathbf{6 a}$ & ASN522, ASP474 & -6.6 to -6.1 & 0 to 27.861 & 0 to 29.449 \\
\hline $\mathbf{6 b}$ & ASN522 (2 Bonds), ASP474 & -6.9 to -6.1 & 0 to 29.795 & 0 to 31.019 \\
\hline $\mathbf{6 c}$ & SER316 & -6.4 to -5.5 & 0 to 29.953 & 0 to 31.984 \\
\hline $\mathbf{6 d}$ & ASN522 (2 Bonds) & -6.7 to -5.5 & 0 to 28.430 & 0 to 30.404 \\
\hline $\mathbf{6 e}$ & SER316 (3 Bonds) & -6.4 to -5.8 & 0 to 32.950 & 0 to 34.903 \\
\hline $\mathbf{6 f}$ & ASN522 (2 Bonds) & -6.4 to -5.8 & 0 to 29.383 & 0 to 31.961 \\
\hline $\mathbf{6 g}$ & TYR497 & -6.2 to -5.7 & 0 to 29.921 & 0 to 31.167 \\
\hline $\mathbf{7 a}$ & No Bonds & -6.4 to -5.7 & 0 to 28.171 & 0 to 29.070 \\
\hline $\mathbf{7 b}$ & ASN261 & -6.3 to -5.5 & 0 to 29.146 & 0 to 32.788 \\
\hline $\mathbf{7 c}$ & SER328 $(2$ Bonds) & -6.3 to -5.7 & 0 to 29.450 & 0 to 31.480 \\
\hline $\mathbf{7 d}$ & SER328 $(2$ Bonds) & -6.7 to -5.6 & 0 to 30.289 & 0 to 31.125 \\
\hline $\mathbf{7 e}$ & ASN261 & -6.1 to -5.5 & 0 to 32.683 & 0 to 34.644 \\
\hline $\mathbf{7 f}$ & ASN261 & -6.2 to -5.6 & 0 to 32.134 & 0 to 33.710 \\
\hline $\mathbf{7 g}$ & ASN261 & -6.3 to -5.6 & 0 to 31.959 & 0 to 33.609 \\
\hline $\mathbf{7 h}$ & ASN261 & -6.1 to -5.2 & 0 to 34.427 & 0 to 36.129 \\
\hline $7 \mathbf{i}$ & ALA 520 & -7.0 to -6.0 & 0 to 26.824 & 0 to 28.108
\end{tabular}

Table 2. Antimicrobial activity of compounds $6 a-i$ and $7 a-i$.

\begin{tabular}{|c|c|c|c|c|c|c|c|}
\hline ن气 & 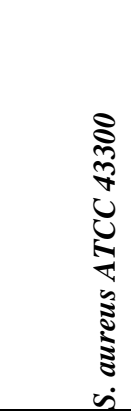 & 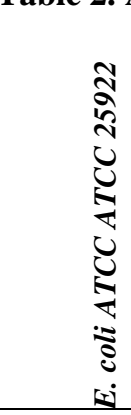 & 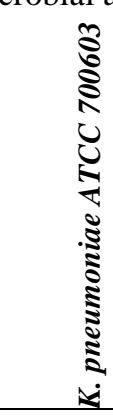 & 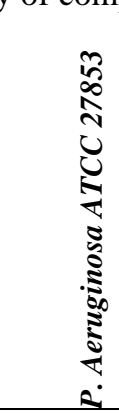 & 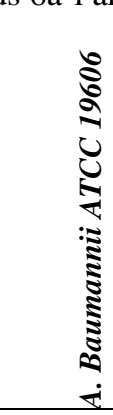 & 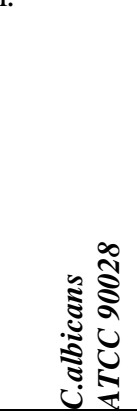 & 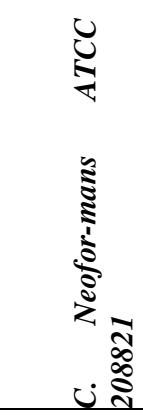 \\
\hline $6 a$ & 2.5 & 9.1 & 11.3 & 8.2 & 15.4 & 33.7 & 14.5 \\
\hline $6 \mathrm{~b}$ & 6.3 & 12.5 & 13.7 & 14.3 & -4.7 & 24.5 & 17.9 \\
\hline $6 \mathrm{c}$ & 34.5 & 15.7 & 28.5 & -5.7 & 11.8 & 6.5 & 11.4 \\
\hline 6d & 32.3 & 15.3 & -5.6 & 14.5 & 14.4 & 13.5 & 13.3 \\
\hline $6 e$ & 53.3 & -11.1 & 10.4 & -0.3 & 11.4 & 15.20 & 34.5 \\
\hline $6 f$ & 72.4 & 13.9 & 15.4 & 14.5 & 23.7 & 11.6 & 41.4 \\
\hline $6 g$ & 23.1 & 4.7 & 0.5 & 6.7 & -1.0 & 2.9 & -0.8 \\
\hline $\begin{array}{l}05 \\
7 a\end{array}$ & 10.4 & 13.2 & 14.5 & 15.3 & 13.3 & 24.3 & 25.1 \\
\hline $7 b$ & 10.6 & 1.5 & 5.4 & 7.1 & 5.0 & 26.9 & 2.7 \\
\hline $7 c$ & 7.5 & -5.6 & -4.3 & -0.4 & 23.7 & 25.6 & -5.7 \\
\hline $7 d$ & 12.4 & 2.6 & 5.8 & 11.4 & -11.2 & 31.3 & 7.5 \\
\hline $7 e$ & 31.0 & 9.2 & 9.2 & 5.0 & 10.3 & 7.1 & -4.7 \\
\hline $7 f$ & 43.1 & 22.43 & -6.1 & 5.5 & 7.3 & 7.5 & 12.4 \\
\hline $7 g$ & 64.4 & 21.5 & 11.3 & 12.4 & 31.2 & 7.5 & 33.7 \\
\hline $7 \mathrm{~h}$ & 23.3 & -10.5 & -8.3 & -23.5 & 5.6 & 3.7 & 21.4 \\
\hline $7 i$ & -4.9 & -5.1 & 5.2 & -1.7 & -3.4 & 4.0 & -3.5 \\
\hline
\end{tabular}

3.3. Evaluation of the antimicrobial activities.

The antimicrobial screening was performed by CO-ADD (the Community for Antimicrobial Drug Discovery) funded by the Wellcome Trust (UK) and the University of 
Queensland (Australia) [52]. The growth inhibition was measured against five bacterial strains (Escherichia coli, Klebsiella pneumoniae, Acinetobacter baumannii, Pseudomonas aeruginosa, and Staphylococcus aureus) and two fungal strains (Candida albicans and Cryptococcus neoformans). The standard concentration employed for the screening was 32 $\mathrm{mg} / \mathrm{mL}$ in DMSO. The observed in vitro antimicrobial activities of our synthesized products 6a-i and 7a-i are tabulated in Table 2.

Analysis of the antimicrobial data revealed that the bacteria Staphylococcus aureus (ATCC 43300) were sensitive to a lesser extent than the fungi Candida albicans ATCC 90028 and Cryptococcus neoformans ATCC 208821 that were found to be more sensitive to the compounds of the analyzed group. Compound 6a,b, 7b,c,d with methyl, ethyl, isopropyl groups contribute to the emergence of activity against Candida albicans (ATCC 90028) (GI in the range of 24.5 - 33.7\%), while electron-withdrawing substituents (chlorine and dichloro-, compounds $6 \mathrm{e}, \mathrm{f}, 7 \mathrm{~g}$ ) caused the enhancement in the sensitivity to fungus Cryptococcus neoformans (ATCC 208821) to these substances (GI in the range of $33.7-41.4 \%$ ). More active compounds and their higher activity were observed in relation to gram-positive bacteria Staphylococcus aureus (ATCC 43300). This applied only to halogen-substituted benzyl derivatives (compounds 6c, d, e, f, 7e, f, g with GI values within 31.0 - 72.4\%). Dichlorosubstituted $6 \mathrm{e}, \mathrm{f}, 7 \mathrm{~g}, \mathrm{GI}=53.3,72.4$, and $64.4 \%$, respectively, differ especially against this background. It should be noted that the substance $7 \mathrm{~g}$ is also characterized by a broader spectrum of activity, involving in its active action on E. Coli ATCC 25922 (GI =21.5\%), A. Baumanii ATCC 19606 (GI = 31.2\%) C. neoformans ATCC 208821 (GI =33.7\%), while the highest rates were in compounds $6 \mathrm{f}(\mathrm{GI}=72.4 \%$ relative to Staphylococcus aureus (ATCC 43300) and GI $=41.4 \%$ relative to Cryptococcus neoformans (ATCC 208821).

\section{Conclusions}

In conclusion, we have displayed that the suggested synthetic protocols provided the opportunity to design of series of new 5-(4-substituted-benzyl)-2-(furan/thiophen-2ylmethylene hydrazono) thiazolidin-4-ones. The structures of aimed substances were reaffirmed by using ${ }^{1} \mathrm{H}-\mathrm{NMR}$ spectroscopy and elemental analysis. The molecular docking study reported the significant $\mathrm{H}$-bonding of the synthesized substances as ligands with the amino acid residues of the receptor GlcN-6P. The performed biological activity evaluation results suggested the synthesized compounds as a promising structure in antimicrobial drug development. Further optimization of the structure to improve biological activity is currently in progress.

\section{Funding}

This research received no external funding.

\section{Acknowledgments}

We are grateful to CO-ADD (the Community for Antimicrobial Drug Discovery) for screening the antimicrobial activity.

\section{Conflicts of Interest}

The authors declare no conflict of interest. 


\section{References}

1. Tomasić, T.; Masic L. Rhodanine as a privileged scaffold in drug discovery. Current Medicinal Chemistry 2009, 16, 1596-1629, https://doi.org/10.2174/092986709788186200.

2. Kaminskyy, D.; Kryshchyshyn, A.; Lesyk, R. 5-Ene-4-thiazolidinones - An efficient tool in medicinal chemistry. European Journal of Medicinal Chemistry 2017, 140, 542-594, https://doi.org/10.1016/j.ejmech.2017.09.031.

3. Kaminskyy, D.; Kryshchyshyn, A.; Lesyk, R. Recent developments with rhodanine as a scaffold for drug discovery. Expert Opinion on Drug Discovery 2017, 12, 1233-1252, https://doi.org/10.1080/17460441.2017.1388370.

4. Fortin, S.; Berube, G.; Advances in the development of hybrid anticancer drugs. Expert Opinion on Drug Discovery 2007, 8, 1547-1577, https://doi.org/10.1517/17460441.2013.798296.

5. Havrylyuk, D.; Roman, O.; Lesyk, R. Synthetic approaches, structure activity relationship and biological applications for pharmacologically attractive pyrazole / pyrazoline-thiazolidine-based hybrids. European Journal of Medicinal Chemistry 2016, 113, 145-166, https://doi.org/10.1016/j.ejmech.2016.02.030.

6. De Monte,C; Carradori, S.; Bizzarri, B.; Bolasco, A.; Caprara, F.; Mollica, A.; Rivanera, D.; Mari, E.; Zicari, A.; Akdemi, A.; Secci, D. Anti-Candida activity and cytotoxicity of a large library of new N-substituted-1,3thiazolidin-4-one derivatives. European Journal of Medicinal Chemistry 2016, 107, 82-96, https://doi.org/10.1016/j.ejmech.2015.10.048.

7. El-Sayed, W.; Abdel-Monem, Y.; Yousif, N.; Tawfek, N.; Shaaban, M.; Abdel-Rahman, A. Antimicrobial activity of new 2,4-disubstituted thiazolidinone derivatives. Zeitschrift fuer Naturforschung, C: Journal of Biosciences 2009, 64, 785-789, https://doi.org/10.1515/znc-2009-11-1205.

8. Oniga, O.; Thierry Ndongo, O.; Moldovan, C.; Tiperciuc, B.; Oniga, S.; Pîrnău, A.; Vlase, L.; Verité, P. Synthesis and antimicrobial activity of some new 2-hydrazone-thiazoline-4-ones. Farmacia 2012, 60, 785797.

9. Belwal, C.; Joshi, K. Synthesis and antimicrobial screening of 2-[(5,6-dimethoxy-2,3-dihydro-1H-inden-1ylidene)hydrazinylidine]-1,3-thiazolidin-4-one and its 5-Arylidine derivatives. Heterocyclic Letters 2014, 4, $65-71$.

10. Hassan, A.; Mohamed, S.; Nasr, M.; El Shaieb, K.; Abdel-Azis, M.; Abdel-Azis, A. Synthesis and antibacterial activity of new substituted ethylidenehydrazinylidene-1,3-thiazol-4-ones. Journal of Chemical Research 2014, 38, 673-678, https://doi.org/10.3184/174751914X14138794305033.

11. Goudreau, N.; Hucke, O.; Faucher, A.M.; Grand-Maître, C.; Lepage, O.; Bonneau, PR.; Mason, SW.; Titolo, S. Discovery and Structural Characterization of a New Inhibitor Series of HIV-1 Nucleocapsid Function: NMR Solution Structure Determination of a Ternary Complex Involving a 2:1 Inhibitor/NC Stoichiometry. Journal of Molecular Biology 2013, 425, 1982-1998, https://doi.org/10.1016/j.jmb.2013.02.022.

12. Abbas, E.; Gomha, S.; Farghaly, T.; Abdalla, M. Synthesis of New Thiazole Derivatives as Antitumor Agents. Current Organic Synthesis https://doi.org/10.2174/1570179412666150828195202.

13. El-Mekabat, A.; Habib, O. Efficient and convenient route to the synthesis of some novel sulfonate esterbased heterocycles as antitumor agents. Heterocycles 2018, 96, 677-689, https://doi.org/10.3987/COM-1813870.

14. Khan, A.; Diwan, A.; Thabet, H.; Imran, M.; Bakht, M. Discovery of novel pyridazine-based cyclooxygenase-2 inhibitors with a promising gastric safety profile. Molecules 2020, 25, https://doi.org/10.3390/molecules25092002.

15. Khan, A.; Diwan, A.; Thabet, H.; Imran, M. Synthesis of novel N-substitutedphenyl-6-oxo- 3phenylpyridazine derivatives as cyclooxygenase-2 inhibitors. Drug Development Research 2020, 81, 573584, https://doi.org/10.1002/ddr.21655.

16. Channar, P.A.; Saeed, A.; Larik, F.A.; Rafiq, M.; Ashraf, Z.; Jabeen, F.; Fattah, T.A. Synthesis, computational studies and enzyme inhibitory kinetics of substituted methyl [2-((4-dimethylaminobenzylidene)-hydrazono)-4-oxo-thiazolidin-5-ylidene]acetates as mushroom tyrosinase inhibitors. Bioorganic \& Medicinal Chemistry 2017, 25, 5929-5938, https://doi.org/10.1016/j.bmc.2017.09.009.

17. Arshad, M.; Ahmad, D.; Akhter, R. 1, 3-thiazolidin-4-one derivatives bearing pyrimidine moieties: Design, computational studies, synthesis, characterization, antimicrobial, MTT assessment and molecular docking assessment. Chemical Data Collections 2020, 28, https://doi.org/10.1016/j.cdc.2020.100405.

18. Arshad, M. Design, Drug-Likeness, Synthesis, Characterization, Antimicrobial Activity, Molecular Docking, and MTT Assessment of 1,3-Thiazolidin-4-one Bearing Piperonal and Pyrimidine Moieties. Russian Journal of Bioorganic Chemistry 2020, 46, 599-611, https://doi.org/10.1134/S1068162020040056.

19. Chaban, T.; Matiychuk, V.; Mahlovanyy, A.; Chaban, I.; Ogurtsov, V.; Lelyukh, M. Antitumor properties of thiazolo[4,5-b]pyridin-2-one derivatives. Biointerface Research in Applied Chemistry 2020, 10, 59445950, https://doi.org/10.33263/BRIAC104.944950.

20. Tupys, A.; Kalembkiewicz, J.; Ostapiuk, Y.; Matiichuk, V.; Tymoshuk, O.; Woźnicka, E.; Byczyński, Ł. Synthesis, structural characterization and thermal studies of a novel reagent 1-[(5-benzyl-1,3-thiazol-2- 
yl)diazenyl]naphthalene-2-ol. Journal of Thermal Analysis and Calorimetry 2017, 127, 2233-2242, https://doi.org/10.1007/s10973-016-5784-0.

21. Chaban, T.I.; Ogurtsov, V.V.; Matiychuk, V.S.; Chaban, I.G.; Demchuk, I.L.; Nektegayev, I.A. Synthesis, anti-inflammatory and antioxidant activities of novel $3 H$-thiazolo[4,5-b]pyridines. Acta Chimica Slovenica 2019, 66, 103-111, https://doi.org/10.17344/acsi.2018.4570.

22. Pokhodylo, N.T.; Matiychuk, V.S. Synthesis of new 1,2,3-triazolo[1,5-a]quinazolinones. Journal of Heterocyclic Chemistry 2010, 47, 415-420, https://doi.org/10.1002/jhet.321.

23. Chaban, T.; Klenina, O.; Chaban, I.; Ogurtsov, V.; Harkov, S.; Lelyukh, M. Thiazolo[5,4-d]pyrimidines and thiazolo[4,5- $d$ ] pyrimidines: A review on synthesis and Pharmacological importance of their derivatives. Pharmacia 2018, 65, 54-70.

24. Obushak, N.D.; Gorak, Yu.I.; Matiichuk, V.S.; Lytvyn, R.Z. Synthesis of heterocycles based on arylation products of unsaturated compounds: XVII. Arylation of 2-acetylfuran and synthesis of 3-R-6-(5-aryl-2furyl)-7H-[1,2,4]triazolo[3,4-b][1,3,4]thiadiazines. Russian Journal of Organic Chemistry 2008, 44, 16891694, https://doi.org/10.1134/S1070428008110213.

25. Chaban, T.; Matiychuk, V.; Ogurtsov, V.; Chaban, I.; Harkov, S.; Nektegaev, I. Synthesis and biological activity of some novel derivatives 5,7-dimethyl-6-phenylazo-3H-thiazolo[4,5-b]pyridine-2-one. Pharmacia 2018, 65, 51-62.

26. Bazel, Y.; Tupys, A.; Ostapiuk, Y.; Tymoshuk, O.; Matiychuk, V. A green cloud-point microextraction method for spectrophotometric determination of $\mathrm{Ni}(\mathrm{II})$ ions with 1-[(5-benzyl-1,3-thiazol-2yl)diazenyl]naphthalene-2-ol. Journal of Molecular Liquids 2017, 242, 471-477, https://doi.org/10.1016/j.molliq.2017.07.047.

27. Chaban, Z.; Harkov, S.; Chaban, T.; Klenina, O.; Ogurtsov, V.; Chaban, I. Recent advances in synthesis and biological activity evaluation of condensed thiazoloquinazolines: A review. Pharmacia 2017, 64, 52-66.

28. Pokhodylo, N.T.; Teslenko, Y.O.; Matiychuk, V.S.; Obushak, M.D. Synthesis of 2,1-benzisoxazoles by nucleophilic substitution of hydrogen in nitroarenes activated by the azole ring. Synthesis 2009, 16, 27412748, https://doi.org/10.1055/s-0029-1216875.

29. Chaban, T.; Ogurtsov, V.; Chaban, I.; Myrko, I.; Harkov, S.; Leluykh, M. Synthesis of some new 4iminothiazolidine-2-ones as possible antioxidants agents. Pharmacia 2019, 66, 27-32, https://doi.org/10.3897/pharmacia.66.e35131.

30. Lozynska, L.; Tymoshuk, O.; Chaban, T. Spectrophotometric studies of 4-[n'-(4-imino-2-oxo-thiazolidin-5ylidene)-hydrazino]-benzenesulfonic acid as a reagent for the determination of Palladium. Acta Chimica Slovenica 2015, 62, 159-167.

31. Pokhodylo, N.T.; Matiychuk, V.S.; Obushak, N.D. Synthesis of 1H-1,2,3-triazole derivatives by the cyclization of aryl azides with 2-benzothiazolylacetonone, 1,3-benzo-thiazol-2-ylacetonitrile, and (4-aryl1,3-thiazol-2-yl)acetonitriles. Chemistry of Heterocyclic Compounds 2009, 45, 483-488, https://doi.org/10.1007/s10593-009-0287-6.

32. Chaban, T.I.; Matiichuk, Y.E.; Horishny, V.Y.; Chaban, I.G.; Matiychuk, V.S. Synthesis and Anticancer Activity of 2-aryl-3-methylbenzofuro[3,2-B]pyrazolo[4,3-E]azepine-4,11(2H,10H)-dione and 2-Aryl-3,7,9trimethylpyrido[3',2':4,5]thieno[3,2-b]pyrazolo[4,3-E]azepine-4,11(2H,10H)-diones. Russian Journal of Organic Chemistry 2020, 56, 813-818, https://doi.org/10.1134/S1070428020050139.

33. Matiichuk, Y.; Ogurtsov, V.; Ostapiuk, Y.; Chaban, T.; Matiychuk, V. Synthesis, anti-inflammatory activity and molecular docking of 2-methyl-3-furamides. Biointerface Research in Applied Chemistry 2020, 10, 5809-5814, https://doi.org/10.33263/BRIAC104.809814.

34. Tymoshuk, O.; Oleksiv, L.; Rydchuk, P.; Chaban, T.; Tymoshuk, S.; Matiychuk, V. Spectrophotometric Study of the Interaction of Platinum(IV) with New Derivatives of Azolidones. Chemistry and Chemical Technology 2020, 14, 139-145, https://doi.org/10.23939/chcht14.02.

35. Chaban, T.; Klenina, O.; Harkov, S.; Ogurtsov, V.; Chaban, I.; Nektegaev I. Synthesis of some new $\mathrm{N}^{3}$ substituted 6-phenylazo-3H-thiazolo[4,5-b]pyridin-2-ones as possible anti-inflammatory agents. Pharmacia 2017, 64, 16-30.

36. Pokhodylo, N.T.; Matiychuk, V.S.; Obushak, N.D. Synthesis of 1H-1,2,3-triazole derivatives by the cyclization of aryl azides with 2-benzothiazolylacetonone, 1,3-benzo-thiazol-2-ylacetonitrile, and (4-aryl1,3-thiazol-2-yl)acetonitriles. Chemistry of Heterocyclic Compounds 2009, 45, 483-488, https://doi.org/10.1007/s10593-009-0287-6.

37. Chaban, T.I.; Matiychuk, V.S. Synthesis of 2-Aryl-5-oxo-5H-thiopyrano[4,3-b]pyridine-7-carboxylic Acids as the First Representatives of a New Heterocyclic System. Russian Journal of General Chemistry 2020, 90, 1578-1580, https://doi.org/10.1134/S1070363220080290.

38. Tymoshuk, O.; Oleksiv, L.; Khvalbota, L.; Chaban, T.; Patsay, I. Spectrophotometric determination of ru(iv) using 5-hydroxyimino-4-imino-1,3-thiazolidin-2-one as a novel analytical reagent. Acta Chimica Slovenica 2019, 66, 62-69, https://doi.org/10.17344/acsi.2018.4448.

39. Chaban, T.; Ogurtsov, V.; Mahlovanyy, A.; Sukhodolska, N.; Chaban, I.; Harkov, S.; Matiychuk, V. Antioxidant properties of some novel derivatives thiazolo[4,5-b]pyridine. Pharmacia 2019, 66, 171-180, https://doi.org/10.3897/pharmacia.66.e36764. 
40. Rydchuk, P.V.; Tymoshuk, O.S.; Oleksiv, L.V.; Chaban, T.I.; Matiychuk, V.S. Voltammetric determination of pt(Iv) using 5-hydroxyimino-4-imino-1,3-thiazolidine-2-one. Methods and Objects of Chemical Analysis 2019, 14, 130-139, https://doi.org/10.17721/moca.2019.130-139.

41. Matiichuk, Y.; Ostapiuk, Y.; Chaban, T.; Ogurtsov, V.; Matiychuk, V. Synthesis and anticancer properties of n-(5-r-benzyl-1,3-thiazol-2-yl)-2,5-dimethyl-3-furamides. Biopolymers and Cell 2020, 36, 74-83, http://dx.doi.org/10.7124/bc.000A22.

42. Horishny, V.; Chaban, T.; Matiychuk, V. Synthesis and Primary Antitumor Screening of 5-Ylidene Derivatives of 3-(Morpholin-4-yl)-2-sulfanylidene-1,3-thiazolidin-4-one. Russian Journal of Organic Chemistry 2020, 56, 454-457, https://doi.org/10.1134/S1070428020030148.

43. Chaban, T.I.; Matiichuk, Y.E.; Matiychuk, V.S. Synthesis of $2 H$-thiopirano[3,4-c]pyrazol-7-one derivatives as the first example a new heterocyclic system. Russian Journal of General Chemistry 2020, 90, 1357-1361, https://doi.org/10.1134/S1070363220070257.

44. Chulovska, Z.; Chaban, T.; Drapak, I.; Chaban, I.; Nektegaev I. Synthesis of some C ${ }^{5}$ substituted 4phenylimino-thiazolidin-2-ones as possible anti-inflammatory agents. Biointerface Research in Applied Chemistry 2021, 11, 8009-8017, https://doi.org/10.33263/BRIAC111.80098017.

45. Drapak, I.; Foliush, V.; Chaban, T.; Matiychuk, V. Synthesis antimicrobial and antitumor activities of 2-[5(2-R-benzyl)thiazol-2-ylimino]thiazolidin-4-ones. Biointerface Research in Applied Chemistry 2020, 10, 5507-5511, https://doi.org/10.33263/BRIAC103.507511.

46. Chaban, T.I.; Matiychuk, V.S.; Ogurtsov, V.V.; Chaban, I.G.; Nektegayev, I.A. Development of effective anti-inflammatory drug candidates among novel thiazolopyridines. Ukrainian Biochemical Journal 2020, 92, 132-139, https://doi.org/10.15407/ubj92.02.132.

47. Klenina, O.; Chaban, T.; Zimenkovsky, B.; Harkov, S.; Ogurtsov, V.; Chaban, I.; Myrko, I. Qsar modeling for antioxidant activity of novel $\mathrm{N}^{3}$ substituted 5,7-dimethyl-3H-thiazolo[4,5-b]pyridin-2-ones. Pharmacia 2017, 64, 49-71.

48. Ostapiuk, Y.V., Chaban, T.I., Matiychuk, V.S. Thiazolidine-2,4-dithione in the Knoevenagel/Hetero DielsAlder Domino Reaction. Russian Journal of Organic Chemistry 2020, 56, 1495-1497, https://doi.org/10.1134/S1070428020080242.

49. Obushak, N.D.; Matiichuk, V.S.; Ganushchak, N.I.; Burlak, Y.É. Synthesis of heterocycles from products of the anion arylation of unsaturated compounds. 3. 2-Arylimino-5-arylmethyl-4-thiazolidones. Chemistry of Heterocyclic Compounds 1998, 34, 492-496, https://doi.org/10.1007/BF02290893.

50. Mouilleron, S.; Badet-Denisot, M.A.; Golinelli-Pimpaneau, B. Ordering of C-terminal loop and glutaminase domains of glucosamine-6-phosphate synthase promotes sugar ring opening and formation of the ammonia channel. Journal of Molecular Biology 2008, 377, 1174-1185, https://doi.org/10.1016/j.jmb.2008.01.077.

51. Trott, O.; Olson, A. AutoDock Vina: improving the speed and accuracy of docking with a new scoring function, efficient optimization and multithreading. Journal of Computational Chemistry 2010, 31, 455-461, https://doi.org/10.1002/jcc.21334.

52. Open-access antimicrobial screening program: https://www.co-add.org/. 